\title{
ANALISIS PENGARUH GAYA TERHADAP FATIGUE LIFE BAJA STRUKTURAL PADA PEGAS DAUN MENGGUNAKAN ANALISIS ELEMEN HINGGA
}

\author{
Amirin Kusmiran ${ }^{1}$ dan Muh. L. Said ${ }^{1}$ \\ ${ }^{1}$ Jurusan Fisika, Fakultas Sains dan Teknologi, Universitas Islam Negeri Alauddin Makassar \\ email: amirin.kusmiran@uin-alauddin.ac.id, muhammadsaidlanto83@gmail.com
}

\begin{abstract}
Leaf spring is one of a component of the vehicle which is used to vibration damping caused by the force. Some of case that occur in the vehicle namely overload where this case can affect to fatigue life of steel leaf spring. One of method that is use to fatigue life prediction is the high fatigue cycle, and this method can be simulated by a finite element method. The numbers of both elements and nodes that have been used in this research are 6961 elements and 14726 nodes, respectively. The magnitude of the force that is applied to prediction fatigue life of leaf spring are $80 \mathrm{KN}, 100 \mathrm{KN}$, and $200 \mathrm{KN}$. Based of the finite element analysis, fatigue life of the force $80 \mathrm{KN}$ longer than force $200 \mathrm{KN}$ and $200 \mathrm{KN}$ was obtained which is a desired $10^{6}$ cycle. Also, the critical value of the fatigue life $80 \mathrm{KN}$ is smaller than $100 \mathrm{KN}$, and $200 \mathrm{KN}$. As such, the force 80 $\mathrm{KN}$ is a recommended as an allowed force which use to vehicle. This value is validated by safety factor analysis where the force allowed as $80 \mathrm{KN}$ with safety factor equal to 2.56 .
\end{abstract}

Keywords: force, fatigue life, finite element analysis.

\section{PENDAHULUAN}

Baja merupakan salah satu material dengan tingkat kekuatan dan kekerasan dapat dirancang. Hal ini disebabkan oleh komposisi dari baja merupakan campuran dari besi dan karbon dengan sifat ductile. Oleh karena itu, baja sering diaplikasikan di industri otomotif sebagai penyangga beban seperti pegas daun yang digunakan di bus, mobil, truk, dan lain-lain. Khususnya pada bus dan truk, beban yang digunakan sering melebihi kapasitas penampungan (overload) sebagaimana yang telah ditetapkan oleh dinas perhubungan. Kelebihan kapasitas (overload) pembebanan tersebut dapat mempercepat umur lelah dari pegas daun baja. Pembebanan overload yang berlangsung secara terus-menerus akan memberikan tekanan yang berubah-ubah pada baja pegas daun (Kong et al., 2016). Tekanan inilah yang akan menyebabkan terjadinya retakan. Selanjutnya, penyebaran retakan secara seragam ke segala arah akan mengakibatkan terjadi patahan. Peristiwa ini dapat berbahaya terhadap keselamatan pada saat berlalu lintas. Permasalahan tersebut dapat diatasi dengan mengetahui batas tekanan atau gaya maksimal yang dapat diredam oleh baja pegas daun. Tekanan maksimal yang dapat diterima oleh baja pegas daun dapat dilakukan secara eksperimen dengan pengujian di laboratorium seperti uji Vickers sebagaimana dinyatakan oleh Fragoudakis, Savaidis, \& Michailidis, 2017, 
dan pendekatan secara numerik maupun analitik (Čular et al., 2020). Salah satu metode yang digunakan untuk mengetahui atau memprediksi umur lelah pada baja pegas secara numerik adalah metode elemen hingga.

Metode elemen hingga salah satu metode numerik yang terus dikembangkan untuk menyelesaikan permasalahan-permasalahan yang berkaitan dengan mekanika suatu material, seperti memprediksi umur lelah material komposit sebagaimana yang telah dilakukan oleh Weng, Wen, \& Zhang, 2017. Dengan metode elemen hingga, peneliti dapat menentukan umur kekelahan baja pegas daun yang digunakan pada transportasi darat dengan cara menggunkan teknik high fatigue cycle.

Salah satu parameter yang digunakan untuk menganalisis fatigue life suatu material adalah dengan analisis tegangan (stress analysis) sebagaimana yang dilakukan oleh Lian \& Yao, 2010. Pada analisis tegangan dianggap bahwa amplitudo adalah konstanta dan hanya tekanan yang mempengaruhi tingkat kelelahan. Pada umumnya, baja pegas daun tidak bekerja pada tekanan atau beban yang tetap atau disebut dengan induksi mekanik. Tekanan yang berubah-ubah akan mengakibatkan perubahan mikrostruktur dari baja. Besar energi yang ditimbulkan oleh tekanan:

$$
W=\sigma \varepsilon+\tau \gamma / 2
$$

dimana $\sigma$ dan $\varepsilon$ adalah normal stress dan shear stress, dan tensil strain range dan shear strain. Dari sudut pandang mekanika retakan yang dinyatakan oleh Anderson,T.L.,2005, bentuk perambatan retakan (crack propagation), yaitu opening mode, in-plane shearing mode, dan out-plane sharing mode seperti pada Gambar 1.

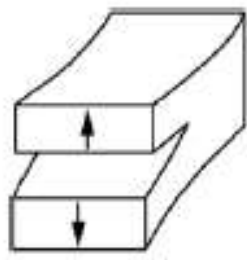

I

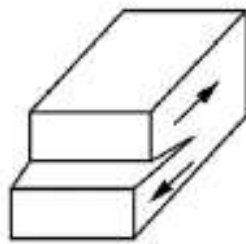

II

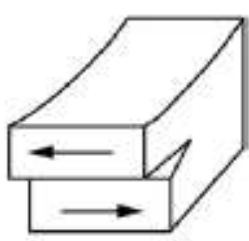

III

Gambar 1. Bentuk-bentuk retakan

Fenomena retakan yang dijelaskan pada gambar 1 yang diakibatkan oleh kelelahan material dapat dianalisis dengan menggunakan beberapa metode, salah satunya adalah metode tegangan siklus high cycle fatigue (S-N) sebagaimana diperlihatkan pada Gambar 2. 


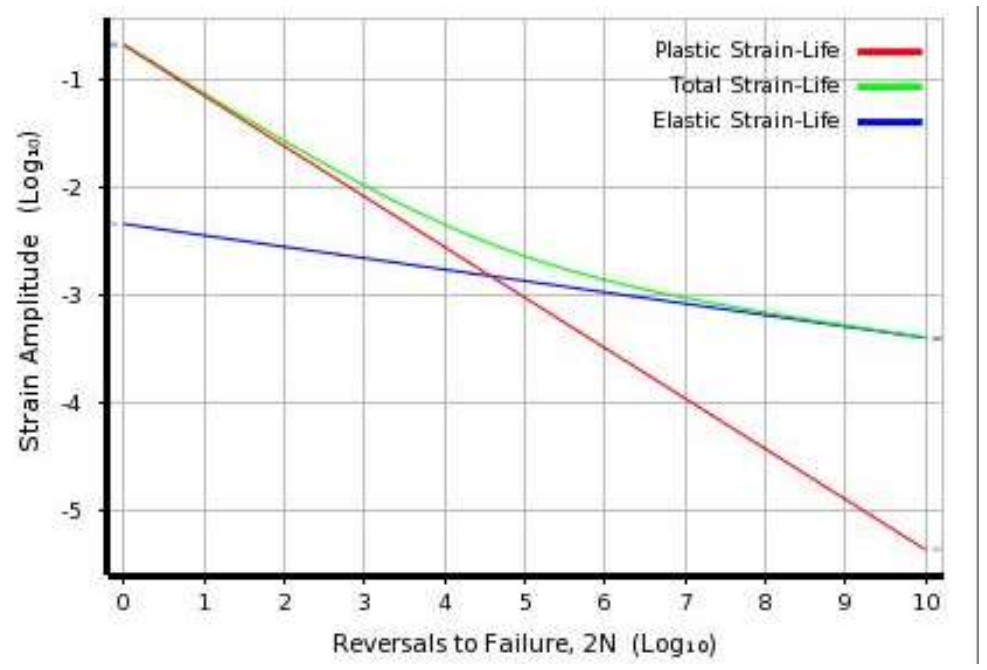

Gambar 2. Pembagian daerah umur lelah dalam kurva S-N.

Metode high cycle fatigue (S-N) merupakan pendekatan pertama untuk memahami fenomena kelelahan logam. Dengan metode ini, umur lelah material dapat diperhitungkan mulai dari tahap inisiasi retak lelah dan tahap umur lelah (crack propagation). Retakan dari material logam dibagikan ke dalam beberapa tipe retakan seperti inisiasi retakan dari inklusi, retakan inklusi dari impinging slip bands, dan retakan emanating (Santecchia et al., 2016).

Umur lelah atau fatigue life material terlebih dahulu dilakukan koreksi-koreksi sesuai dengan sifat mekanik atau jenis material. Beberapa jenis koreksi yang dapat diterapkan pada material untuk melakukan analisis umur lelah, seperti koreksi Goodman, Soderberg, dan Gerber (Zhu et al., 2017). Pada penelitian ini, material yang digunakan untuk merancang pegas daun baja dengan karakteristik seperti pada Tabel 1 adalah baja struktural. Sifat dari baja ini adalah ductile sehingga koreksi yang digunakan untuk mengetahui umur lelah pegas daun baja adalah Gerber dengan amplitudo konstan (Kluger, 2015) seperti pada gambar 3.

Constant Amplitude Load

Fully Reversed

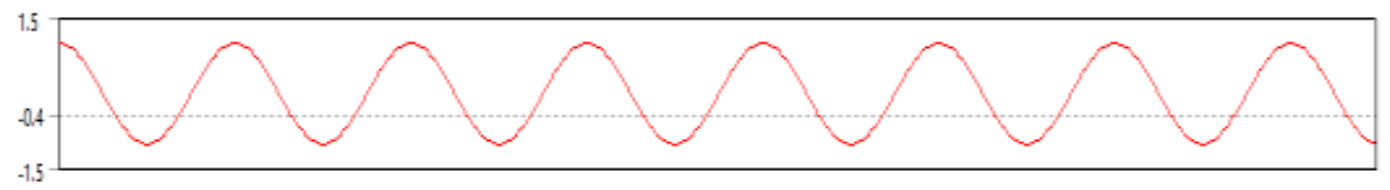

Mean Stress Correction Theory

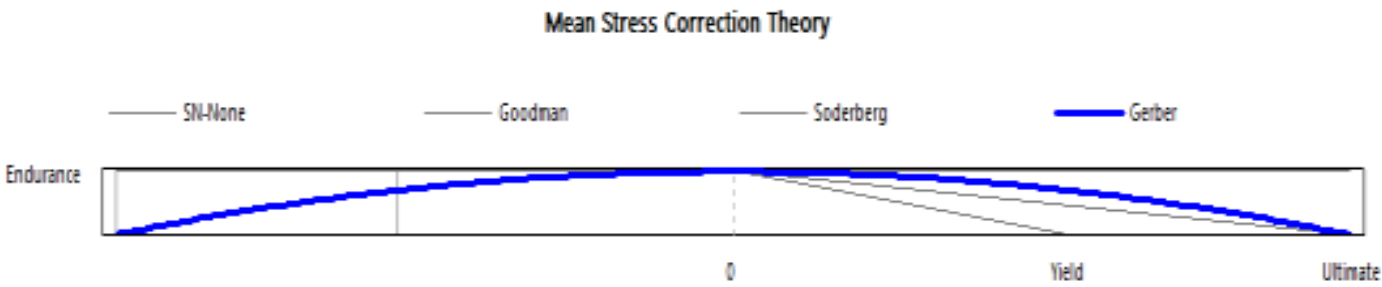

Gambar 3. Koreksi Goodman untuk analisis fatigue life pada pegas daun baja 
Gambar 3 memperlihatkan bahwa pembebanan yang diberikan kepada pegas daun baja adalah pembebanan yang konstan sebesar $80 \mathrm{KN}, 100 \mathrm{KN}$, dan $200 \mathrm{KN}$. Koreksi yang digunakan pada gambar 3 telah memenuhi model skematik diagram Gerber yang telah dinyatakan oleh Zhu et al., 2017 dimana diperlihatkan pada gambar 4.

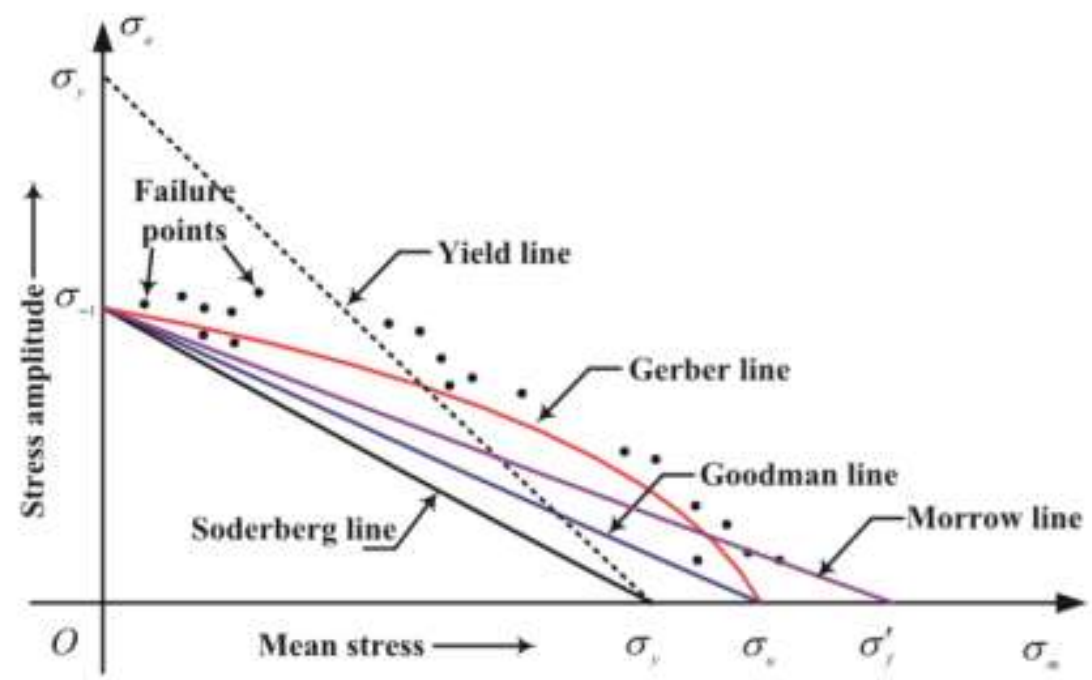

Gambar 4. Model koreksi Gerber, Goodman, dan Morrow (Zhu et al., 2017)

dimana $\sigma_{y}$ adalah yield strength, $\sigma_{u}$ adalah ultimate tensile strength, $\sigma_{f}^{\prime}$ adalah fatigue strength coefficient, dan $\sigma_{m}$ adalah tensile sumbuh- $x$.

\section{METODE PENELITIAN}

Penelitian ini dilakukan dengan menggunakan metode elemen hingga yang telah terintegrasi dengan perangkat lunak ansys. Metode ini digunakan untuk mencari nilai fatigue dari material. Langkah-langkah penelitian diperlihatkan pada Gambar 5.

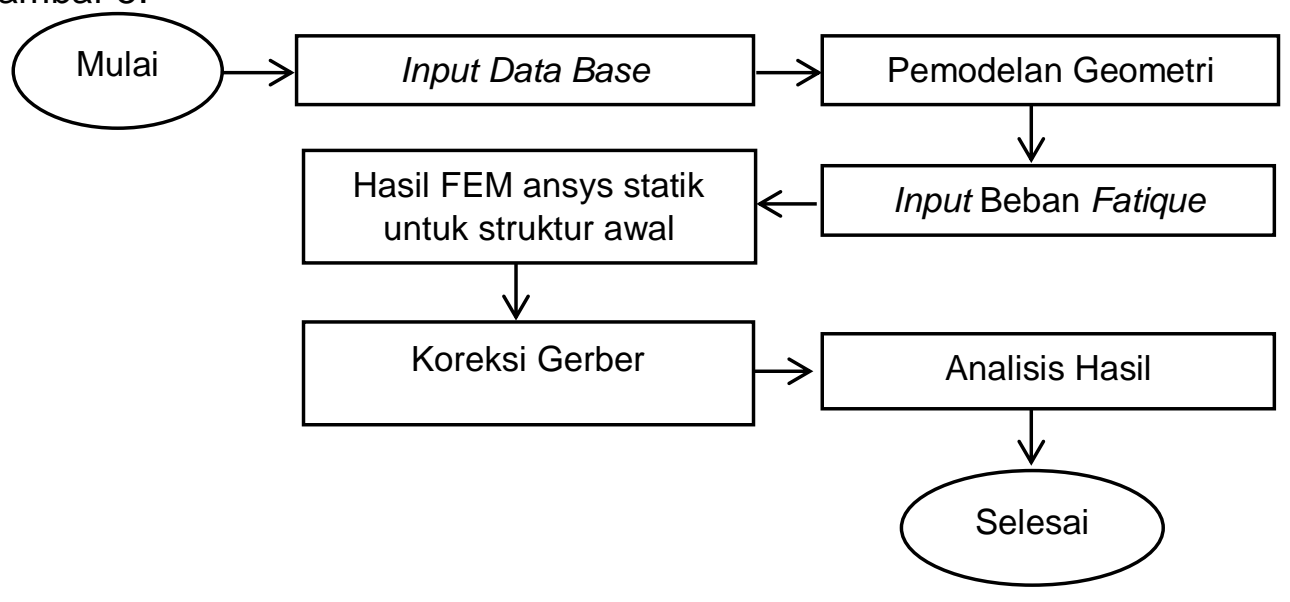

Gambar 5. Rancangan penelitian 
Gambar 5 memberikan gambaran terhadap tahapan-tahapan pelaksanaan penelitian, yakni: Mempersiapkan model pegas daun seperti Gambar 6 dengan menggunakan software design modeler yang telah terintegrasi dengan software ansys 19.0.

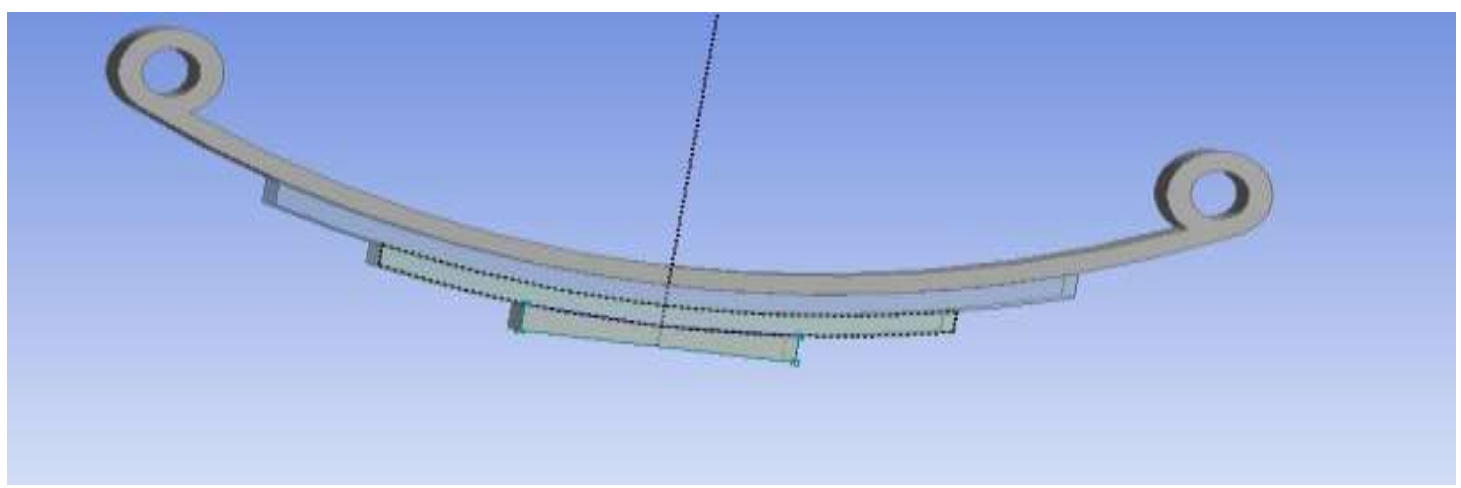

Gambar 6 Perancangan pegas daun 4 lapis.

setelah perancangan pegas daun selesai, tahapan selanjutnya memilih material yang digunakan, yakni baja struktur dengan sifat fisis seperti pada Tabel 1.

Tabel 1 Sifat fisis dan mekanik baja struktur.

\begin{tabular}{clll}
\hline No. & Sifat Fisik/Mekanik & Nilai & Satuan \\
\hline 1 & Density & 7850 & $\mathrm{Kg} / \mathrm{m}^{3}$ \\
2 & Tensile yield strength & 250 & $\mathrm{MPa}$ \\
3 & Compressive Yield strength & 250 & $\mathrm{MPa}$ \\
4 & Tensile ultimate strength & 460 & $\mathrm{MPa}$ \\
5 & Isotropic thermal conductivity & 60,5 & $\mathrm{~W} / \mathrm{mC}$ \\
6 & Specific heat & 434 & $\mathrm{~J} . \mathrm{KgC}$ \\
7 & Isotropic relative permeability & 10000 & \\
8 & Isotropic Resistivity & $1,7 \times 10^{-7}$ & $\Omega \mathrm{m}$ \\
\hline
\end{tabular}

Selain memasukan jenis material yang digunakan, mendefinisikan jenis sambungan atau kontak yang digunakan antar lapisan pada pegas daun, dimana kontak yang digunakan pada penelitian ini adalah bounding contact. Mendefinisikan mesh yang digunakan, dimana mesh yang digunakan pada penelitian ini adalah triangle mesh seperti pada gambar 7 , dan memastikan bahwa mesh yang digunakan tidak error. 


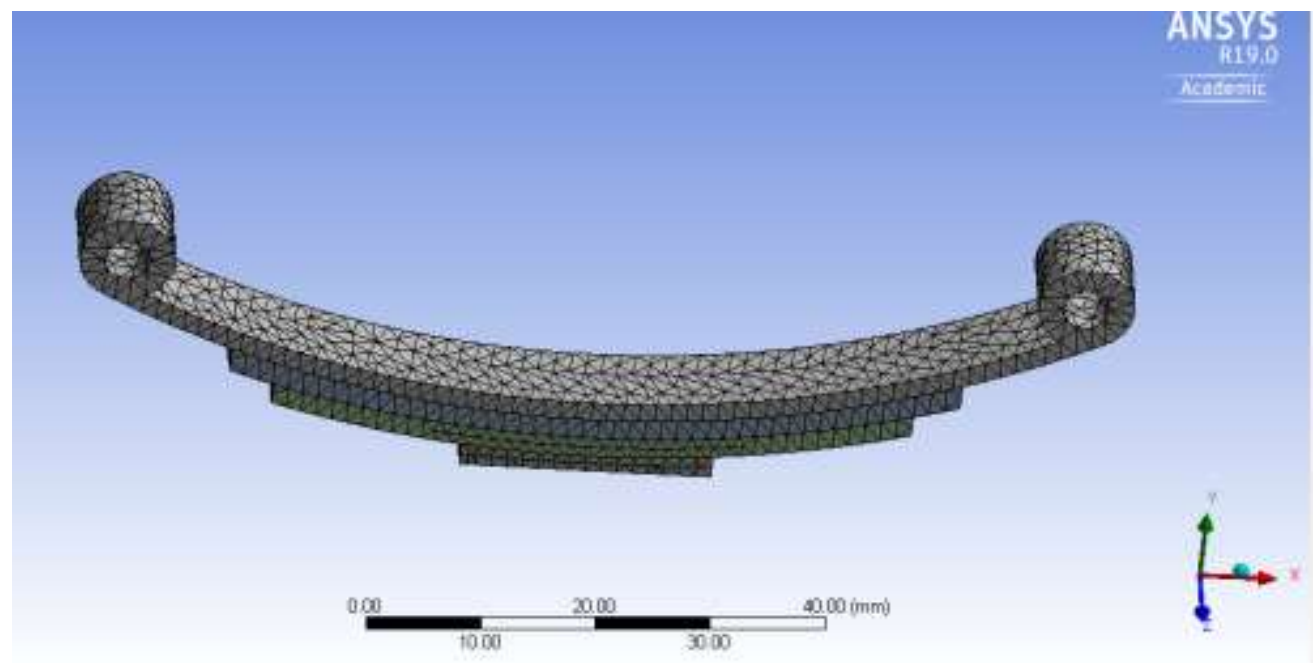

Gambar 7 Mesh elemen hingga pada pegas daun baja

Jumlah mesh yang diperoleh dari Gambar 7 sebanyak 6.961 elemen dan 14.726 nodes. Setelah itu, kondisi batas dan pembebanan pada struktur pegas daun baja dimasukan, seperti gambar 7 .

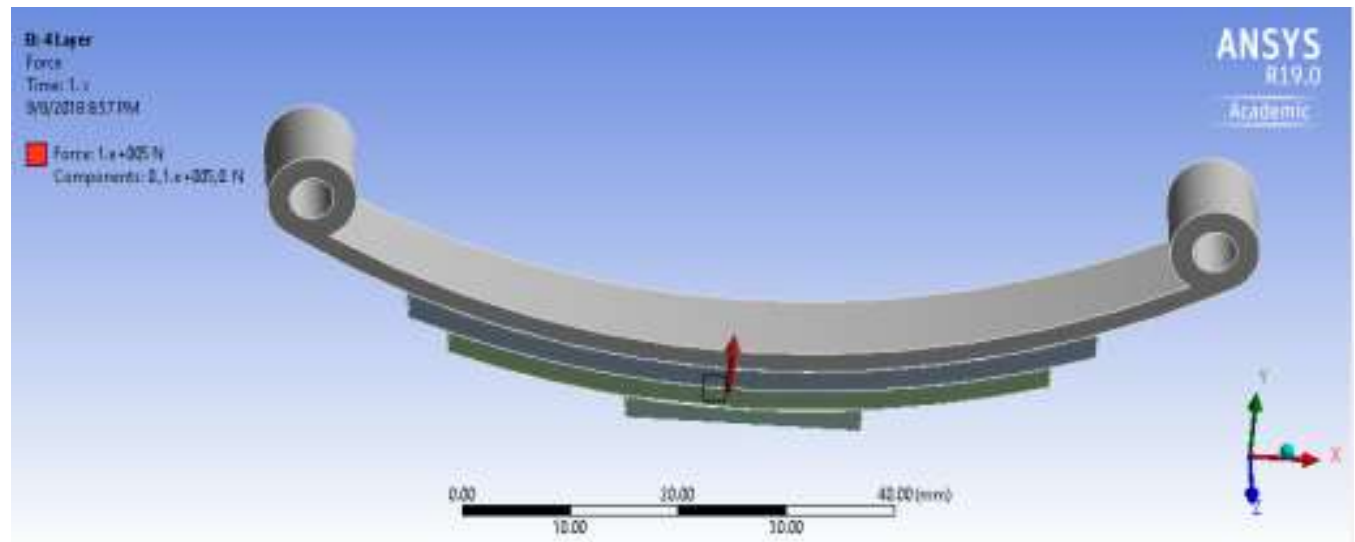

Gambar 8 Pembebanan pada struktur pegas daun baja

Kedua ujung dibatasi dengan kondisi fix point, dan besar beban yang digunakan pada penelitian ini sebesar $80 \mathrm{KN}, 100 \mathrm{KN}$, dan $200 \mathrm{KN}$. Tahapan terakhir adalah memberikan jenis analisis yang digunakan untuk menentukan fatigue. Analisis yang digunakan analisis statik dan analisis fatigue. Salah satu koreksi yang digunakan untuk menentukan fatigue life material adalah koreksi Gerber seperti pada gambar 3 dan gambar 4. 


\section{HASIL DAN PEMBAHASAN}

Penelitian ini dilakukan dengan tujuan untuk mendapat umur fatigue dari struktur pegas daun baja dengan memberikan pembebanan sebesar $80 \mathrm{KN}, 100 \mathrm{KN}$, $200 \mathrm{KN}$. Hasil dari pembebanan tersebut diperlihatkan pada gambar 9, gambar 10, dan gambar 11.

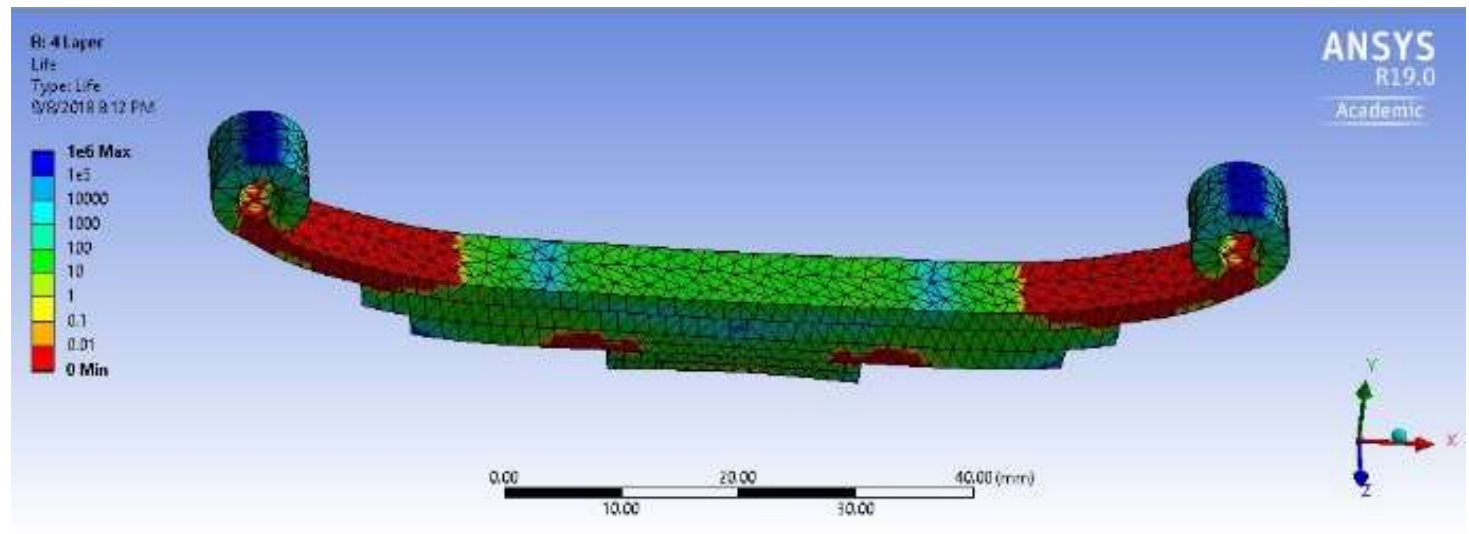

Gambar 9 Fatigue life dengan gaya sebesar $80 \mathrm{KN}$.

Gambar 9 memperlihatkan umur lelah atau kondisi fatigue pada struktur pegas daun yang telah diberikan beban sebesar $80 \mathrm{KN}$, dimana struktur pegas daun baja terlihat distribusi umur fatigue. Siklus maksimal pada struktur terebut sebesar $10^{6}$ siklus. Nilai tersebut mengindikasikan bagian tersebut tidak akan megalami kerusakan selama siklus terjadi pada struktur. Hal ini relevan dengan penelitian yang telah dilakukan oleh Topaç et al., 2012. Gambar 9 terdapat bagian-bagian yang siklus yang kurang dari $10^{6}$, seperti distribusi hijau 100 siklus, warna biru 1000 siklus, dan 0,01 siklus. Perbedaan distribusi tersebut menunjukan adanya pengurangan tegangan atau gaya akibat dari pengaruh jarak (Anderson, 2016). Siklus minimal berada pada warna merah dengan siklus sebesar 0,01 siklus. Siklus minimal ini menunjukan bahwa daerah-daerah tersebut akan mengalami kerusakan lebih awal dibandingkan dengan bagian yang lain.

Pembebanan dapat mempengaruh daya tahan dari struktur pegas daun baja sebagaimana yang diperlihatkan oleh Gambar 10 dan Gambar 11. Gambar 10 menunjukan daerah kritis semakin luas karena diakibatkan oleh adanya pembebanan sebesar $100 \mathrm{KN}$. Siklus minimal pada warna merah terjadi pada bagian ujung kiri dan kanan. Penomena seperti ini disebabkan oleh adanya tegangan yang terkonsentrasi pada kedua ujung pegas. Hal ini dapat terjadi disebabkan oleh kedua ujung pegas daun dijadikan sebagai titik diam atau dikenal dengan fix point, sehingga membuat struktur tersebut menjadi rigid. Untuk melihat dampak dari adanya pembebanan terhadap struktur pegas daun baja, pembebanan diberikan sebesar $200 \mathrm{KN}$. 


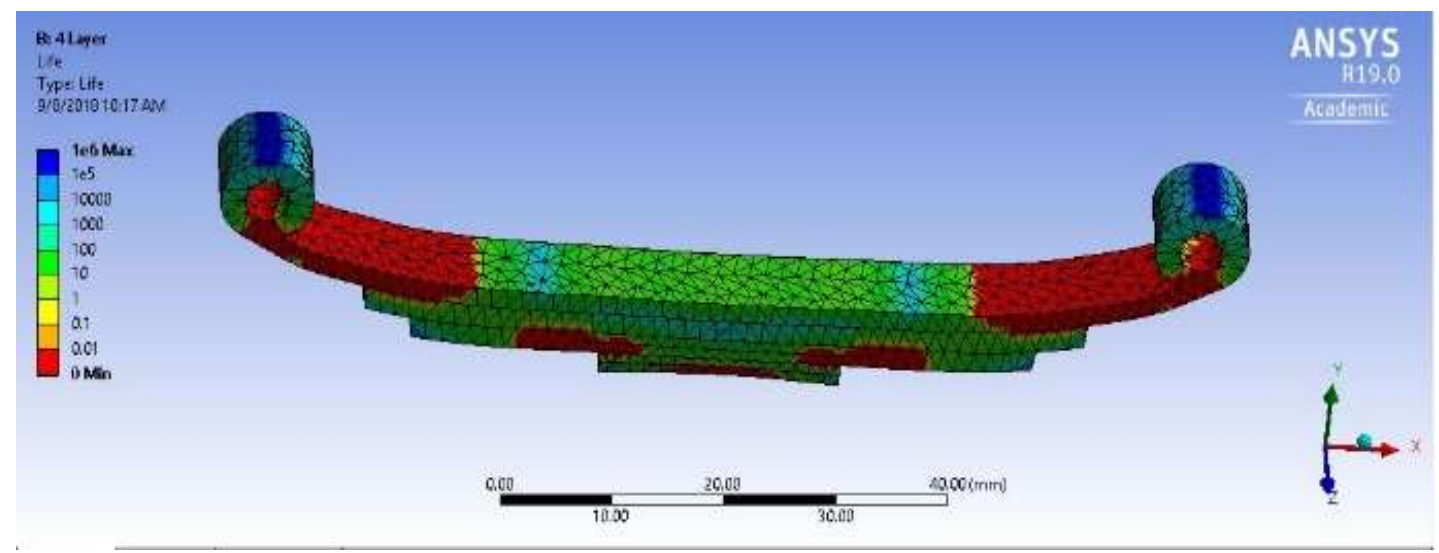

Gambar 10. Fatigue life dengan gaya sebesar $100 \mathrm{KN}$.

Hasil dari pembebanan tersebut diperlihatkan oleh gambar 10. Gambar tersebut memperlihat secara jelas distribusi warna merah yang mempunyai siklus sebesar 0,01 siklus hampir merambat pada seluruh bagian struktur pegas daun baja. Distribusi dari siklus ini menunjukan bahwa struktur pegas daun baja mengalami overload sehingga cepat mengalami retakan. Dengan demikian pada pembebanan dengan $200 \mathrm{KN}$ tidak rekomendasi pada kendaraan yang menggunakan pegas daun baja dengan sifat fisis seperti pada Tabel 1.

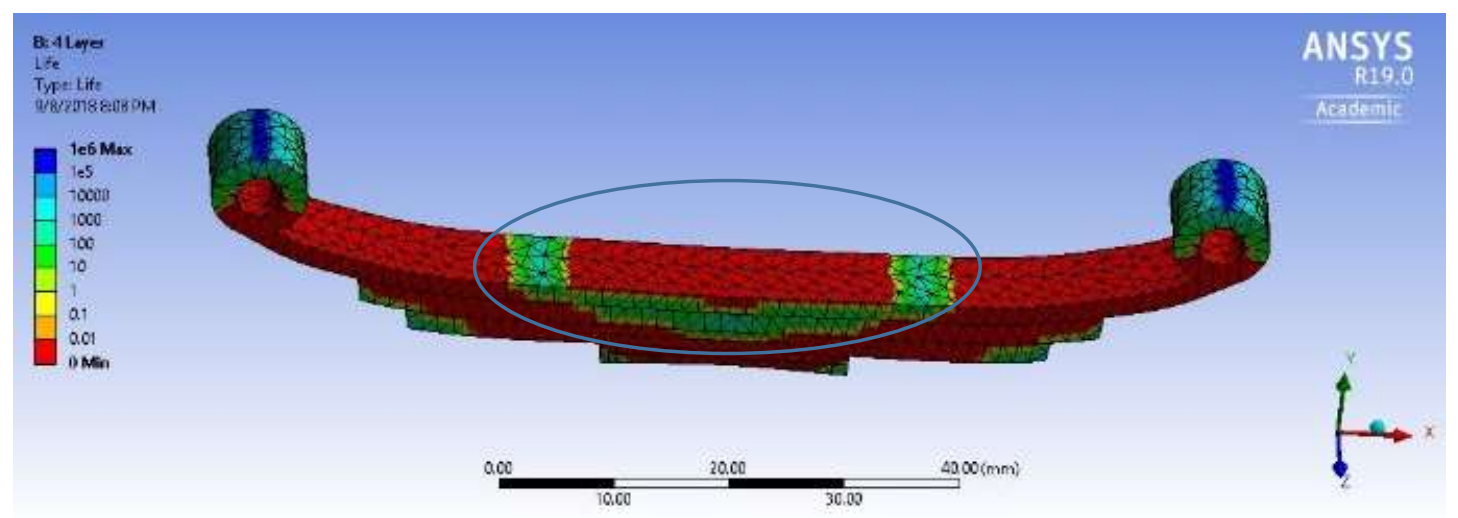

Gambar 11 Fatigue life dengan gaya sebesar 200 KN.

Gambar 11 juga memberikan informasi mengenai sifat fisis yang digunakan pada material baja struktur, dimana sifat fisis tidak terdistribusi secara merata ke segala arah secara homogen, sehingga pada bagian-bagian tertentu tidak mengalami siklus yang sama, seperti yang ditunjukan pada elips di gambar 11 .

Faktor keamanan diterapkan untuk mengantisipasi gaya atau beban yang terjadi pada komponen permesinan agar komponen tersebut tidak gagal (failure). Semakin terkendali beban yang tejadi pada komponen semakin kecil faktor keamanan yang dapat diterapkan, dan sebaliknya. Besar safety factor dapat mempengaruhi tegangan yang diijinkan pada material sebagaimana diperlihatkan 
pada gambar 11. Gambar ini memperlihatkan safety factor maksimal yang dihasilkan oleh pemebebanan $200 \mathrm{KN}$ sebesar 2,52. Safety factor ini memberikan informasi bahwa tegangan ijin dari pegas daun baja sebesar $80 \mathrm{KN}$.

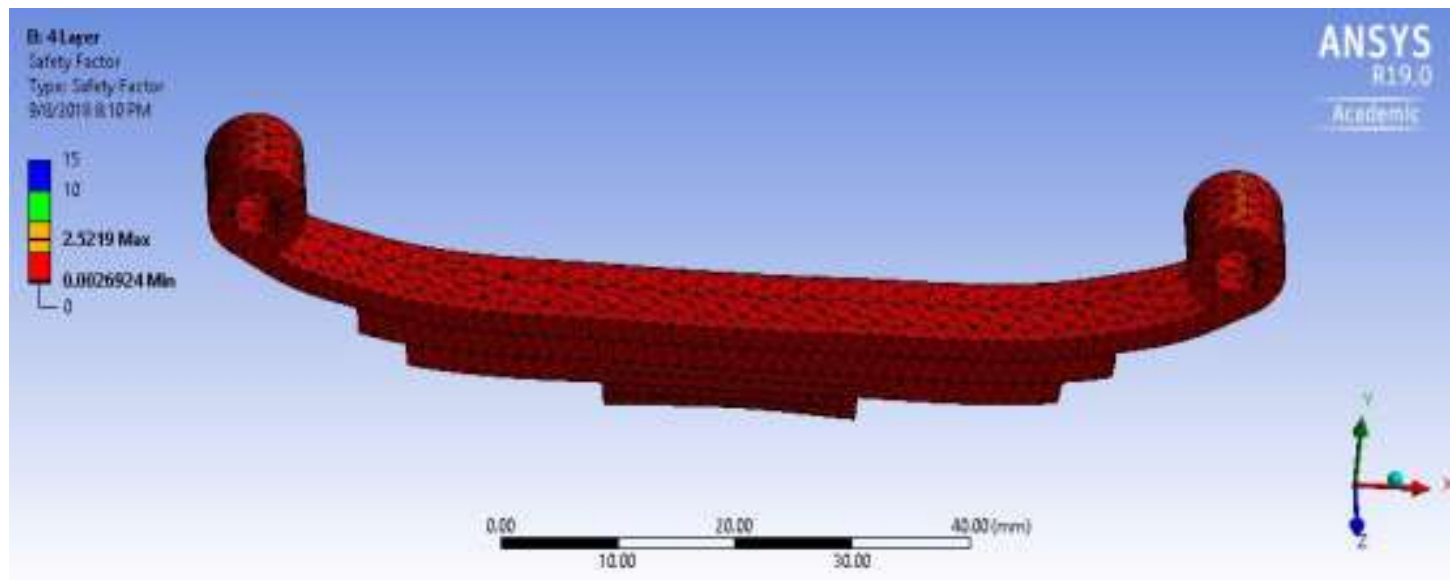

Gambar 12. Safety factor $200 \mathrm{KN}$.

Gambar 9, gambar 10, dan gambar 11 memberikan gambaran besar beban optimal yang dapat diberikan kepada pegas daun baja. dimana besar beban optimal yang dapat diberikan adalah $80 \mathrm{KN}$.

\section{SIMPULAN}

Berdasarkan uraian diatas, umur kelelahan atau fatigue life struktur pegas daun dapat diprediksikan dengan menggunakan metode elemen hingga. Hasil penelitian ini menunjukan siklus maksimum sebesar $10^{6}$ siklus. Siklus ini menunjukan bahwa bagian tersebut tidak mengalami kerusakan selema suspensi terjadi. Besar gaya maksimal yang bisa digunakan pada struktur pegas daun baja dengan sifat fisis seperti pada Tabel 1 sebesar 100 KN. Selain itu, Besar gaya 200 $\mathrm{KN}$ tidak direkomendasikan untuk digunakan. Hal ini disebabkan distribusi siklus minimal 0,01 siklus hampir merata disepanjang struktur pegas daun baja. Pada peneltian ini, siklus 0,01 siklus menunjukan nilai kritis yang mempunyai umur lelah yang cepat, sehingga akan mengalami kerusakan yang lebih cepat. Selain itu, berdasarkan safety factor, besar gaya yang diijinkan yakni sebesar $80 \mathrm{KN}$ dengan safety factor sebesar 2,5.

\section{DAFTAR PUSTAKA}

Anderson, T.L. (2016). Fracture Mechanics Fourth Edition. CRC Taylor \& Francis.

Čular, I., Vučković, K., Žeželj, D., \& Glodež, S. (2020). Analytical approach for low and high cycle bending fatigue life prediction of carburized gear steel specimens. Engineering Failure Analysis, 108, 104328. https://doi.org/10.1016/j.engfailanal.2019.104328 
Fragoudakis, R., Savaidis, G., \& Michailidis, N. (2017). Optimizing the development and manufacturing of $56 \mathrm{SiCr} 7$ leaf springs. International Journal of Fatigue, 103, 168-175. https://doi.org/10.1016/j.ijfatigue.2017.05.016

Kluger, K. (2015). Fatigue life estimation for 2017A-T4 and 6082-T6 aluminium alloys subjected to bending-torsion with mean stress. International Journal of Fatigue, 80, 22-29. https://doi.org/10.1016/j.jjfatigue.2015.05.005

Kong, Y. S., Abdullah, S., Omar, M. Z., \& Haris, S. M. (2016). Failure assessment of a leaf spring eye design under various load cases. Engineering Failure Analysis, 63, 146-159. https://doi.org/10.1016/j.engfailanal.2016.02.017

Lian, W., \& Yao, W. (2010). Fatigue life prediction of composite laminates by FEA simulation method. International Journal of Fatigue, 32(1), 123-133. https://doi.org/10.1016/j.ijfatigue.2009.01.015

Santecchia, E., Hamouda, A. M. S., Musharavati, F., Zalnezhad, E., Cabibbo, M., El Mehtedi, M., \& Spigarelli, S. (2016). A Review on Fatigue Life Prediction Methods for Metals [Research article]. Advances in Materials Science and Engineering. https://doi.org/10.1155/2016/9573524

Topaç, M. M., Ercan, S., \& Kuralay, N. S. (2012). Fatigue life prediction of a heavy vehicle steel wheel under radial loads by using finite element analysis. Engineering Failure Analysis, 20, 67-79. https://doi.org/10.1016/j.engfailanal.2011.10.007

Weng, J., Wen, W., \& Zhang, H. (2017). Multiaxial fatigue life prediction of composite materials. Chinese Journal of Aeronautics, 30(3), 1012-1020. https://doi.org/10.1016/j.cja.2017.03.019

Zhu, S.-P., Lei, Q., Huang, H.-Z., Yang, Y.-J., \& Peng, W. (2017). Mean stress effect correction in strain energy-based fatigue life prediction of metals. International Journal of Damage Mechanics, 26(8), 1219-1241. https://doi.org/10.1177/1056789516651920 